\title{
Discussion: The Poole and Perry Reports
}

JAMES TOBIN NOTED that an equitable price guideline would imply price declines in industries in which productivity growth was particularly rapid. $\mathrm{He}$ felt that, in practice, some of these industries would pose especially difficult problems for a wage-price policy. George Perry observed that this problem would be minimized if the target of policy were a modest rate of inflation, such as $2 \frac{1}{2}$ percent, rather than complete price stability.

James Duesenberry thought that existing labor contracts calling for substantial wage increases, about which Poole expressed concern, were a valid problem for a new policy. Arthur Okun agreed that this was a problem in some individual contracts. But most three-year contracts were front-loaded, with large increases in the first year and moderate ones-6 percent or soin the second and third years. In this case, the post-freeze policy could accept the wage increases provided for in existing contracts.

Franco Modigliani said that until just recently he had been thinking in terms of a model in which the recent wage increases were fundamentally big-union increases. In the late 1960s, the relative wages of the high-wage unions had decreased compared with those in the rest of the economy, and this was followed by some catching up. But recent events suggested to him that the pressure may be coming equally from the nonunionized sector, which nobody plans to control directly.

In reply, Duesenberry agreed with Perry's paper, noting that the rise in nonunion wages did not reflect labor shortages. It occurs because, with prices rising rapidly and big increases in the visible settlements, employers 
believe that the wages they pay must keep pace if they are to maintain their positions as good employers. He called attention to the system of wage surveys used to establish nonunion wages. Banks, insurance companies, department stores, and even the federal government are granting wage increases on the basis of comparability, as determined by wage surveys. These wage increases would not have accelerated without tight labor markets. But after the market pressure evaporated, there was nothing to stop the process from continuing. In this situation, a standard for the visible, wellorganized sector would result in a wage slowdown elsewhere in the economy as well. 